\title{
A CASE STUDY ANALYSIS INFORMING A SET OF RECOMMENDATIONS FOR THE SUCCESSFUL IMPLEMENTATION OF CARBON PRICING INSTRUMENTS FOR TORONTO, CANADA
}

\author{
By \\ Laura Brown, \\ B.A. (Hons), University of Toronto, 2014 \\ A Major Research Paper \\ presented to Ryerson University \\ in partial fulfillment of the requirements for the degree of \\ Master of Planning \\ in \\ Urban Development
}

Toronto, Ontario, Canada, 2017

(C) Laura Brown 2017 


\section{Author's Declaration for Electronic Submission of a MRP}

I hereby declare that I am the sole author of this MRP. This is a true copy of the MRP, including any required final revisions.

I authorize Ryerson University to lend this MRP to other institutions or individuals for the purpose of scholarly research

I further authorize Ryerson University to reproduce this MRP by photocopying or by other means, in total or in part, at the request of other institutions or individuals for the purpose of scholarly research.

I understand that my MRP may be made electronically available to the public. 


\title{
A CASE STUDY ANALYSIS INFORMING A SET OF RECOMMENDATIONS FOR THE SUCCESSFUL IMPLEMENTATION OF CARBON PRICING INSTRUMENTS FOR TORONTO, CANADA
}

\author{
(C) Laura Brown 2017 \\ Master of Planning \\ in \\ Urban Development \\ Ryerson University
}

\begin{abstract}
This paper provides a set of recommendations for how the City of Toronto can implement a successful carbon pricing instrument highlighting the importance of Municipal Governments in combating climate change. Through examining the successes and failures of 4 other cities around the world that have enacted carbon pricing instruments a set of criteria has been created. This set of criteria informs 4 specific recommendations for the City of Toronto.
\end{abstract}

Key Words: City of Toronto, Municipal Governments, Carbon Pricing, Climate Change 


\section{Acknowledgements}

I would like to acknowledge my supervisor, Dr. Christopher De Sousa for his guidance and assistance on this paper. I would also like to thank my second reader, Dr. Pamela Robinson for her expertise. 
Table of Contents

Author's Declaration for Electronic Submission of a MRP

Abstract

Acknowledgements

Table of Contents

List of Figures

vi

List of Tables

vi

1. Introduction

2. Context

The History of Carbon Pricing 5

The History of Municipalities in Canada and their Role in Climate Change 6

$\begin{array}{lr}\text { Climate Change and the City of Toronto } & 8\end{array}$

3. Methods

4. Analysis

Case study \#1- Saitama, Japan

Background

Outcomes- Lessons Learned

Case Study \#2- Shenzhen, China

Background

Outcomes- Lessons Learned

Case Study 3- Boulder, Colorado

Background

Outcomes- Lessons Learned

Case Study \#4- London, England

Background

Outcomes- Lessons Learned

5. Discussion/ Recommendations

Recommendation \#1

Recommendation \#2

36

Recommendation \#3

37

Recommendation \#4

6. Limitations

7. Conclusion

42

8. References 


\section{List of Figures}

Figure 1. Location of Toronto, Canada (Google Maps, 2017) 9

Figure 2. Location of Saitama, Japan (Google Maps, 2017) 17

Figure 3. Location of Shenzhen, China (Google Maps, 2017) 20

Figure 4. Location of Boulder, Colorado (Google Maps, 2017) 24

Figure 5. Location of London, England (Google Maps, 2017) 29

\section{List of Tables}

Table 1. Summary of Characteristics

Table 2. List of Criteria for a Successful Carbon Pricing Instrument at the Local Level 32

Table 3. Highlighted Criteria for Successful Carbon Pricing Instruments 


\section{Introduction}

The sustainability of planet earth is in jeopardy. Climate change, the long-term alteration of global climate patterns is the threat. Specifically, the changes in temperature as a result of increased levels of atmospheric carbon dioxide $\left(\mathrm{CO}_{2}\right)$. Over that past 140 years the earth has seen as increase in its temperature by 1.53 degrees Fahrenheit (Intergovernmental Panel on Climate Change, 2014). The last two decades were recorded as the hottest in 400 years (Intergovernmental Panel on Climate Change, 2014). This increase in temperature is directly correlated with the level of $\mathrm{CO}_{2}$ in the atmosphere. The level of $\mathrm{CO}_{2}$ in the atmosphere is higher than it has ever been in the past 400,000 years (Intergovernmental Panel on Climate Change, 2014). It is the first time in recorded history that the amount of $\mathrm{CO}_{2}$ in the atmosphere has surpassed 400 parts per million (Intergovernmental Panel on Climate Change, 2014). This increase in temperature and atmospheric $\mathrm{CO}_{2}$ is having detrimental impacts on the planet from rising sea levels, flooding in coastal areas to droughts in agricultural lands. These changes in climate are not only causing havoc on the environment but are also socially and economically detrimental and will continue to provide more havoc with time if nothing is done to address climate change. According to the Intergovernmental Panel on Climate Change, an increase of more than $2^{\circ} \mathrm{C}$ in the temperature above pre-industrialized levels would lead to a dangerous level of climate change (Intergovernmental Panel on Climate Change, 2014). In order to combat this, industrialized countries must reduce their greenhouse gas emissions by $25-40$ percent below the 1990 level by 2020 (Intergovernmental Panel on Climate Change, 2014).

With atmospheric $\mathrm{CO}_{2}$ steadily increasing since the onset of the Industrial Revolution, and the harm that it is happening environmentally, socially, and economically, governments around the world are beginning to realize the importance of reducing these harmful emissions. 
To date, the focus has been on higher levels of government (Federal) implementing strategies to assist with the reduction of $\mathrm{CO}_{2}$. There are two main tools that are commonly utilized today: cap and trade systems and carbon taxes (David Suzuki Foundation, 2014). A cap and trade system is based on an economic system that sets an upper limit or a cap on the amount of carbon that can be produced by a company and allows for a company to buy/ trade additional carbon credits from companies that have not reached the upper limit (David Suzuki Foundation, 2014). The upper limit of carbon should be reduced each year in order to see significant changes in the reduction of greenhouse gases. The system must be designed properly and with the necessary extensive administrative support in order to be effective. On the other hand a carbon tax is a fee that is charged to companies for the detriment that they have caused towards the environment mainly from the burning of fossil fuels (David Suzuki Foundation, 2014). The setting of the price will impact upon the extent of new greener technology being implemented. This system is much faster for governments to implement. Debates as to which system is more effective are still ongoing however the specific context of the jurisdiction and the policy objectives of the jurisdiction are often what dictate which system is utilized, regardless the purpose of each system is the same- to reduce the amount of atmospheric $\mathrm{CO}_{2}$.

It is important to note that for the most part, the implementation of carbon pricing is happening at the national and sub national level of government (Innovation Network for Communities, 2015). Yet, in today's society where over $50 \%$ of the population is residing in cities and this percentage is expected to climb to $66 \%$ within the next three decades it is necessary to look at how municipal governments can successfully implement carbon pricing instruments. Cities and their complex urban systems are particularly prone to the impacts of the changing climate (Salon et al, 2010). However, municipal governments, have the capacity to take 
proactive measures and influence the urban form and the emissions that are coming from the individual, household and community level (Salon et al, 2010). Through city planning and strategic zoning, municipal governments can alter things such as the amount of travel time needed the mode of travel used, how energy efficient buildings are and the materials that are used in this construction (OECD, 2014). Municipal governments are also in close contact with businesses and residents putting them in an ideal position to influence behavioural patterns. It is estimated that two- thirds of the world's $\mathrm{CO}_{2}$ emissions are coming from activities that are occurring in cities and cities are going to be the ones who are paying for the increase in costs related to the damage caused by climate change (OECD, 2014). Thus, investigating how the municipal government can successfully reduce $\mathrm{CO}_{2}$ emissions through carbon pricing instruments is vital to the sustainable growth of cities for residents and businesses.

Examining the successes and failures of other cities around the world that have enacted carbon pricing mechanisms at the local scale will help to inform how municipal governments can successfully implement carbon pricing instruments to reduce atmospheric $\mathrm{CO}_{2}$. For the purpose of this paper, Canada's most populous city, Toronto, will act as the focus for this examination. A snapshot of what the current status is in the City in relation to its carbon footprint and what has been done to date regarding it will follow. This context will provide necessary information in order to understand the municipal government's role in the reduction of atmospheric $\mathrm{CO}_{2}$. It is important to note that the findings that arise from this study have the potential to be applied to other Canadian Municipalities looking to implement carbon pricing. Prior to looking into the context of Toronto, this paper will begin by looking at what has lead to the implementation of carbon pricing around the world, from there a narrowing down of scope will occur to look at an 
overview of Municipalities in Canada and their role in climate change and finally a look into Toronto. 


\section{Context}

\section{The History of Carbon Pricing}

The implementation of carbon pricing dates back to the year 1990. 1990-2005 marks the first distinct phase of three in the development of a carbon tax (World Bank Group, 2016). During this period eight progressive countries, all located within Europe (Finland, Poland, Sweden, Norway, Denmark, Latvia, Slovenia and Estonia) developed carbon pricing instruments.

2005-2011 marked the second phase in the introduction of carbon pricing (World Bank Group, 2016). This period was highlighted with the development of the Kyoto Protocol and the implementation of the European Union Emissions Trading Scheme (EU ETS) which both helped with the expansion of carbon reduction. The Kyoto Protocol is an international treaty which came out of the 1992 United Nations Framework Convention on Climate Change and is based on countries signing up to reduce their greenhouse gas emissions. There is a larger burden placed on developed countries opposed to developing countries as they are seen to be contributing to higher levels of greenhouse gases. The EU ETS is used as a tool to reduce greenhouse gas emissions and is the first major carbon market that works as a cap and trade system. The trading scheme is now in its third phase and is operating in 31 different countries and covers $45 \%$ of the EU's greenhouse gas emissions.

The third phase is the current day (2012-present), highlighted by the decline in the Kyoto Protocol and an increase in new national and sub national carbon pricing instruments (World Bank Group, 2016). This phase is also highlighted by the 21 st Conference of the Parties (COP21) and the Paris Agreement which came out of and became active as of November 4th, 2016. World leaders came to an agreement to keep global temperature increases below $2^{\circ} \mathrm{C}$. In 
total, 189 countries which is the equivalent of $96 \%$ of the global greenhouse gas emissions have committed to reduce their emissions through their intended nationally determined contributions (INDC, n.d.). The agreement encourages all countries to make individual and voluntary commitments in order to reach the global goal. In order for countries to be able to reach their INDC, governments must have in place policies and programs to ensure sustained efforts in the reduction of greenhouse gases. Investments and consumption patterns that are made every day by firms and households must be changed to reach the global target.

There are currently 40 national and 24 sub national jurisdictions that have implemented carbon pricing instruments (World Bank Group, 2016). Together these pricing instruments make up the equivalent of about $13 \%$ of the annual global greenhouse gas emissions. The majority of these emissions are priced at less than $\$ 10.00 / \mathrm{tCO} 2 \mathrm{e}$ (ton of carbon dioxide equivalent). This price is said to be too low in order to stop the $2^{\circ} \mathrm{C}$ increase in the temperature that will lead to a dangerous level of climate change according to the IPCC. The price of carbon needs to be in the range of $\$ 80.00 / \mathrm{tCO} 2 \mathrm{e}$ to $\$ 120.00 / \mathrm{tCO} 2 \mathrm{e}$ in order to keep the temperature from climbing (World Bank Group, 2016). Despite the progress that has been made to date in the expansion of carbon pricing, this is still only the beginning stages of the implementation of carbon pricing instruments and there is still much political support that needs to occur to ensure that carbon is being priced at the proper rate and that policies are successfully implemented.

\section{The History of Municipalities in Canada and their Role in Climate Change}

Canadian Municipalities have historically played a key, leadership role in the fight against climate change. Since 1901, the Federation of Canadian Municipalities has been the voice for municipalities at the national scale. The Federation represents $90 \%$ of the country's municipal population and has a specific focus on the promotion of sustainable municipalities 
(Federation of Canadian Municipalities, 2017). Specifically, the Federation has a program called the Partners for Climate Protection which came into effect in 1994. This program focuses on Canadian Municipal Governments that have committed to reducing greenhouse gas emissions. There are now over 300 municipalities participating in the program and working towards a reduction in their emissions. This program is the Canadian component of the International Council for Local Environmental Initiatives (ICLEI) - Cities for Climate Protection which is a sustainability network of over 1,100 communities worldwide that are implementing local climate change initiatives that are having a global impact. The Federation also has in place the Municipalities for Climate Innovation Program which provides funding, training and resources to assist municipalities with the reduction of greenhouse gases. This is a five-year, $\$ 75$ million program funded by the Government of Canada. Funding can be secured for plans, studies, projects and support for employee salaries to plan and implement climate change projects that revolve around asset management, energy, greenhouse gas reductions, transportation, waste, and water. The Federation also has in place the Green Municipal Fund to support sustainable community development. Through these funding sources for Municipalities, they have the capacity to control their emissions. It is estimated that Municipalities control 50\% of the country's emissions and they have the ability to reduce the County's emissions by 20-55 mega tonnes (Federation of Canadian Municipalities, 2017). It is vital that Cities are recognized as international leaders in climate action and have the capacity to put into place actions independent of Federal and Provincial levels of government (Gore, Robinson, \& Stern, 2012). Municipalities have historically and will continue to play a crucial role in combating climate change. 


\section{Climate Change and the City of Toronto}

As previously mentioned, The City of Toronto will be the focus for this study. This section will aim to provide an overview of climate change and the policy work or lack thereof that has been done to date in the city within the larger framework of the Country. The City of Toronto is located in Southwestern Ontario, and is the country's most populous city and economic hub. Its current population is just over 2.8 million people and this number is expected to grow to over 7 million by 2050 (Government of Ontario, 2017). Over 20\% of the population in the province lives within the City of Toronto. As of 2016, Canada stated that all provinces must adopt some form of carbon pricing by 2018 or it will be imposed upon them. The province of Ontario has recently taken steps to enact a form of the cap and trade system where businesses who are either electricity importers, or a facility or natural gas distributer that emit 25,000 tonnes or more of greenhouse gas emissions per year, or a fuel supplier that sells more than 200 litres of fuel per year must participate in the program (Ministry of Environment and Climate Change, 2017). To provide an understanding of how much 25,000 tonnes of greenhouse gas emissions is, it is the equivalent to either 4791 personal vehicles driven for a year or 2395 home's energy usage for one year. The implementation of the cap and trade system in the Province is a step in the right direction but there are still questions surrounding what the role of the local government will be and subsequently what the role of the individual, household and community is in the reduction of greenhouse gases. The remainder of this section will provide context on what the City of Toronto has done to date regarding the recording of its emissions and subsequent reports that have arisen from this. 


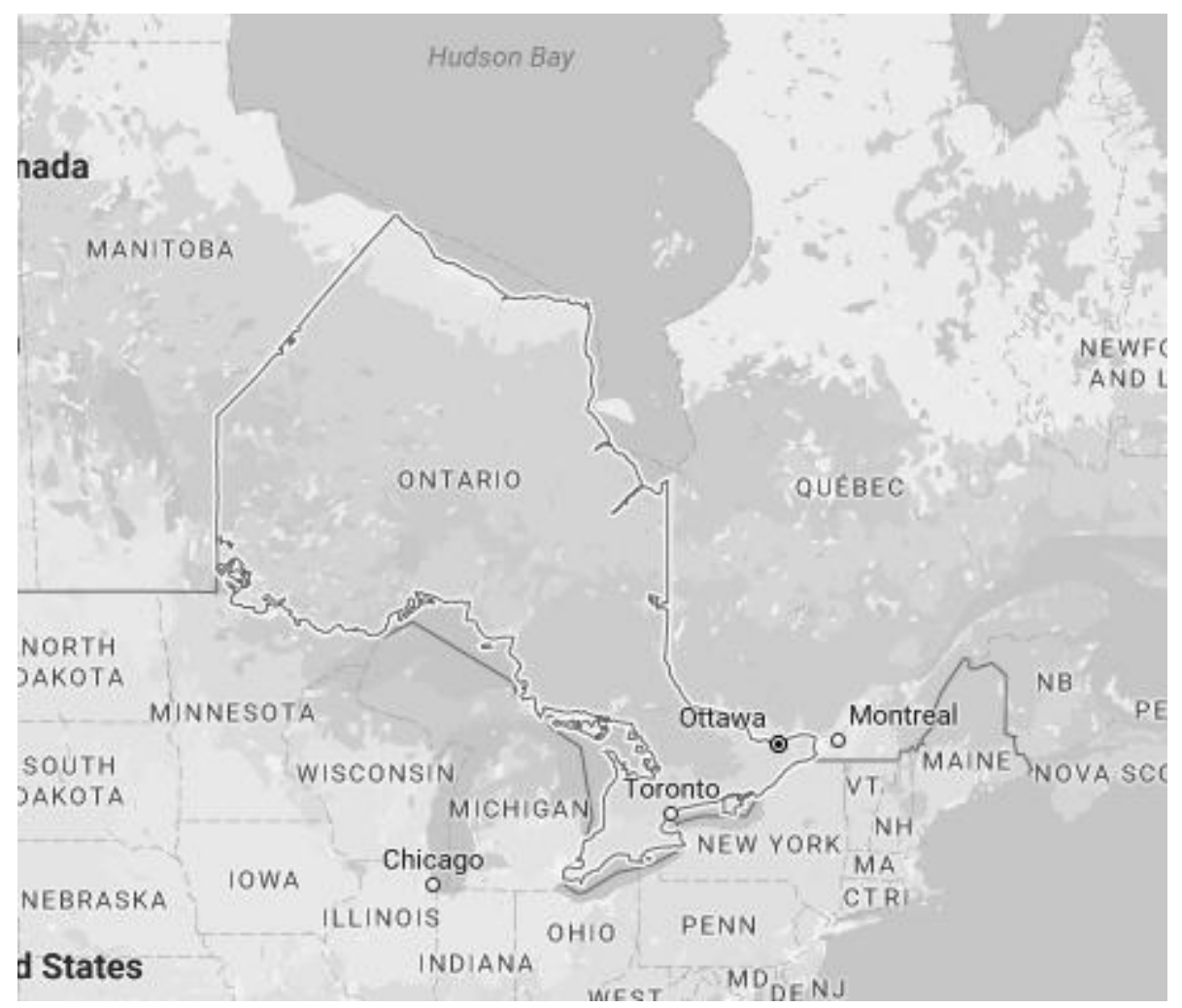

Figure 1. Location of Toronto, Canada (Google Maps, 2017) 
In 1988, Toronto hosted one of the first international meetings to address climate change, called the Toronto Conference on the Changing Atmosphere. This resulted in voluntary targets for reductions in emissions being set. Toronto's target was a reduction of $20 \%$ by 2005 . This led the City to begin the recording of greenhouse gas emissions but it was not until 2004 that the city put together a comprehensive, integrated survey of the emissions (City of Toronto, 2007b, June). This reporting was also the first that had been done since post amalgamation. This took the form of a report that was put out in 2007 titled 'Greenhouse Gas and Air Pollutants in the City of Toronto- toward a Harmonized Strategy for Reducing Emissions'. This report took an in-depth look at emissions from both the community context and also the emissions that were being put out by the City's own operations. The report came to the conclusion that the three main sources of emissions are natural gas burning (residential and commercial buildings), electricity production and burning of gasoline/ diesel (cars and trucks) (City of Toronto, 2007b, June). Following the release of this report there have been some updates to the recording of emissions, however due to constraints in resources much of the data is outdated (ex. The most up-to date data on transportation emissions is from 2008) (City of Toronto, 2015). However, the most up-to date snapshot of the breakdown of sectors and their corresponding greenhouse gas emissions is broken down as follows: $53 \%$ from the buildings, 35\% from the transportation, $11 \%$ from waste, and $1 \%$ fugitive.

Following the release of this report the City also put out a report titled 'Change is in the Air- Climate Change, Clean Air, and Sustainable Energy Action Plan: Moving from Framework to Action' (City of Toronto, 2007a). The purpose of this report was to take what came out of the 2007 report- 'Greenhouse Gas and Air Pollutants in the City of Toronto- toward a Harmonized 
Strategy for Reducing Emissions' and come up with a set of recommendations that would engage the community to take steps to reduce greenhouse gas emissions.

These recommendations were then translated into the project titled Transform TO (City of Toronto, 2016). It highlights that the city will attempt to reduce its greenhouse gas emissions by $80 \%$ by the year 2050 . The project will be used to inform a short term and a long term climate strategy. Despite these actions there is still a remaining 8.7 million tonne gap between what the projected greenhouse gas emissions will be in 2050 and what the low carbon target is for 2050. A study put out by the City titled 'Toronto's Future Weather and Climate Driver Study' looked at what the future weather of Toronto will look like if emissions remain at the same level that they are at today (City of Toronto, 2011). The city can expect to see a daily maximum temperature of $44^{\circ} \mathrm{C}$ compared to the current $37^{\circ} \mathrm{C}$. The number of days above $30^{\circ} \mathrm{C}$ will be 66 compared to the current 20 days and the length of extended heat waves will increase from 0.6 to 2.5 per year.

Rainfall will also increase to 166 millimeters daily compared to the current 66 millimetres. This increase in temperature and rainfall will be detrimental to the suitability of the City's infrastructure and the well being of the City's residents. Therefore, taking a critical look at how municipal governments can successfully implement carbon pricing mechanisms to assist with the reduction of greenhouse gases is necessary. 


\section{Methods}

In order to come up with a set of recommendations that can be used to inform the implementation of carbon pricing instruments for the City of Toronto or any other municipal government within the country, the selection of local governments that have already implemented pricing was necessary for this study. In order to ensure the successful, thorough compilation of local governments that have enacted carbon pricing instruments selecting local governments were divided based on those that have implemented broad strategies of carbon pricing mechanisms meaning that multiple sectors are being covered by the pricing mechanisms and those that have implemented carbon pricing instruments that target a specific sector or action.

This process began with looking at local governments that have enacted carbon pricing instruments that target multiple sectors. The following document, 'State and Trends of Carbon Pricing 2016' which was produced by the World Bank Group was consulted as it solely focuses on governments that have enacted carbon pricing mechanisms at a broad level, covering multiple sectors (World Bank Group, 2016). This document is published each year with an up to date overview of existing and emerging carbon pricing instruments around the world including at the national and sub national level. The World Bank Group is a reputable source of information as it functions as an international organization that is comprised of 184 member countries that are all shareholders in the International Bank for Reconstruction and Development which is what the World Bank was formed under.

In order to make sure that the information that was presented in this document was accurate it was cross referenced with information that was provided by the International Carbon Action Partnership (International Carbon Action Partnership, 2017c). This is an international 
forum that was founded in 2007 for governments and public authorities that have or are planning to implement carbon pricing instruments. It provides an opportunity for leaders to share best practices and discuss the design elements of carbon pricing instruments.

From reviewing the information put out by the World Bank Group and the International Carbon Action Partnership a group of local governments that have enacted broad carbon pricing instruments were selected to inform the set of recommendations. In total there are currently 64 jurisdictions that have implemented or are planning to implement carbon pricing instruments (World Bank Group, 2016). These instruments are divided into three different categories: national (country), sub-national (provinces) and cities. The selection process led to the narrowing down and elimination of pricing instruments that fell under the national and sub-national level. The pricing instruments that were remaining and that fall under the city level include the cities: Rio de Janeiro, Sāo Paulo, Beijing, Tianjin, Shanghai, Chongqing, Shenzhen, Tokyo, Saitama, and Kyoto. This list was further reduced through the elimination of Rio de Janeiro and Sāo Paulo as these two cities have not yet implemented their carbon pricing instruments. From the remaining cities, one from China and one from Japan were selected: Saitama (Japan) and Shenzhen (China). These two cities were selected as the ones with broad ranging climate pricing instruments because they most closely resemble the size of the City of Toronto which makes forming a set of recommendations for the City more accurately informed.

The selection of local governments that have enacted carbon pricing instruments that target a specific sector was based on a popular media scan as there is currently no consolidated database for cities that have enacted carbon pricing instruments that target a specific sector. Following this media scan the following cities were selected based on their implementation of a carbon pricing instruments that targets a specific sector: Boulder, Colorado and London, 
England. These two cities were selected because they differ in terms of Boulder having enacted a price on the carbon itself in the form of a carbon tax and London having enacted a price on the carbon-emitting behavior and not the emissions themselves. Thus, these two cities provide two different approaches to sector specific carbon pricing mechanisms that will assist with the set of informed recommendations for the City of Toronto.

A case study for each of the four cities will follow which will be accompanied by an examination into the successes and failures of each carbon pricing mechanism. These successes and failures will work towards the formation of a set of criteria/ recommendations for a successful carbon pricing instrument. It is important to note that due to the different scales that accompany the carbon pricing instruments at the broad level and at the specific sector/action level directly comparing the instruments together may not always be beneficial. Regardless, each case study will provide valuable information to assist with the formation of a set of criteria/ recommendations for local governments to implement carbon pricing instruments. Following the case studies a summary table is provided (table 1). 


\section{Analysis}

\section{Case Study \#1- Saitama, Japan \\ Background}

Saitama, a major city located to the North of Tokyo along the eastern shores of the country has a population of roughly 1.26 million. It is predominantly a commercial business city with a manufacturing sector focusing on automobiles, food, and optical and pharmaceutical products. The total greenhouse gas emissions for the city are $38.5 \mathrm{MtCO}_{2} \mathrm{e}$ (International Carbon Action Partnership, 2017b). The current breakdown in percentage of the City's emissions by sector is the following: industry- $32.3 \%$, transportation- $29.6 \%$, residential- $23.5 \%$ and commercial- 14.6\% (International Carbon Action Partnership, 2017b).

In April 2011 the city implemented a broad strategy emissions trading system that targets several sectors as part of their wider Saitama Prefecture Global Warming Strategy Promotion Ordinance. This is a long term strategy that focuses on the reduction of carbon in the atmosphere through local governmental action. Saitama's system covers the commercial and industrial sector (International Carbon Action Partnership, 2017b). Facilities that consume energy more than $1,500 \mathrm{~kL}$ of crude oil or more per year must participate in the reduction of their emissions (International Carbon Action Partnership, 2017b). This includes in total 568 facilities within the city with two- thirds of the facilities falling under the industrial sector. Annual reporting must be done on the following seven greenhouse gases: $\mathrm{CO} 2, \mathrm{CH} 4, \mathrm{~N} 2 \mathrm{O}, \mathrm{PFCs}, \mathrm{HFCs}, \mathrm{SF} 6$ and NF3. It is important to note that Saitama's system is bi-laterally linked to Tokyo's (International Carbon Action Partnership, 2017b).

The current emissions trading system is divided into two tracking periods. The first period was from April 1st 2011- 2014 and the second period is from 2015 to 2019. For each 
period there is an absolute cap placed on emissions at the facility level which then aggregates to a city wide cap (International Carbon Action Partnership, 2017b). During the first period emissions had to be reduced by 6 to $8 \%$ below their base year emissions where the base year emissions were calculated based on the average emissions of three consecutive fiscal years from 2002-2007. The higher range of $8 \%$ is for office buildings, public institutions and commercial buildings and the lower end of the range is for factories, water supply and sewage facilities, and solid waste management facilities. Throughout the second period, emissions had to further be reduced by $13-15 \%$ below base year emissions. This is known as the compliance factor. To determine what the exact absolute cap is, the following calculation is done:

sum of base year emissions of covered facilities $\mathrm{x}$ compliance factor $\mathrm{x}$ number of years of a compliance period (first period- 4 years, second period- 5 years )

Throughout the compliance period there is some flexibility in the system for facilities. Banking of credits is allowed between compliance periods but only if the compliance periods are consecutive in order (International Carbon Action Partnership, 2017b). This means that a facility can use credits from the first to second compliance period but not from the first to the third compliance period. Borrowing is also not allowed in this system. The system also allows for credits if facilities engage in excess reduction actions. Credits can be granted for: utilizing renewable energy (ex. Solar, wind, geothermal electricity production), having forests located outside of the city centre, reducing emissions from small/medium size facilities that are not covered by the emissions trading scheme and emissions that are reduced in large facilities that are located outside of Saitama. As well, excess credits can be traded between Saitama and Tokyo, as previously mentioned they have a system that is bi-laterally linked. 


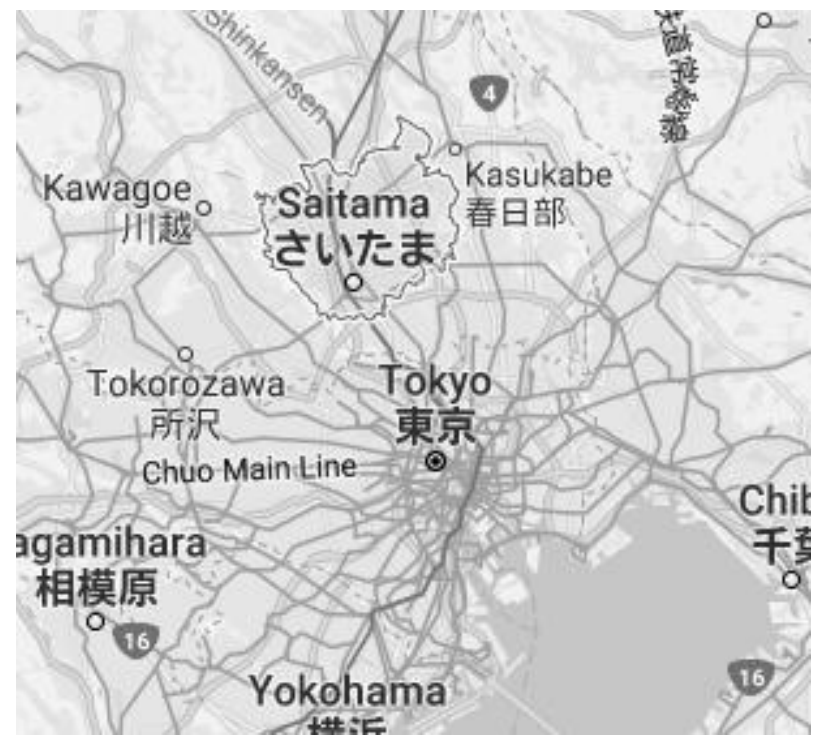

Figure 2. Location of Saitama, Japan (Google Maps, 2017)

\section{Outcomes- Lessons Learned}

Following the end of the first compliance period that concluded in 2014, Saitama reduced its emissions by $24 \%$ below its base-year emissions (International Carbon Action Partnership, 2017b). This success can be attributed to several different factors. As previously mentioned, Saitama's emissions trading scheme is embedded within Saitama Prefecture Global Warming Strategy Promotion Ordinance. Embedding the scheme within current policy has proven to be more beneficial as opposed to having the scheme as a standalone policy. By having the scheme embedded within an already existing document this means that the goals for the future as well at the methods to reach these goals are seen as one holistic process. It encourages facilities to plan for their energy savings and to be fully engaged with reducing their emissions to reach the City's goals.

Another factor that led to the success of Saitama's emissions trading scheme is the fact that much of the data and reporting for facilities was already done prior to the implementation of the scheme (World Bank Group, 2013). Prior to the scheme coming into place in, Saitama had in place an Environmental Damage Reduction Program where targeted facilities had to do mandatory emission reporting. Having this data in place years prior to the implementation of the 
scheme meant that there was already an essential dataset in place that would be used in the designing of the scheme. As well, this also meant that there were expertise in place that would have experience with the monitoring, reporting and verification of emissions.

Saitama's emissions trading scheme also prospered because of its ability for flexibility (World Bank Group, 2013). Facilities have the option to engage in activities that provide them with additional credits and have the option to trade these credits with Tokyo's emissions trading scheme. This flexibility is essential to ensuring that facilities continue to actively engage and participate in the reduction of emissions and assisting the City with meeting its long term goals.

Despite the factors that contributed to the success of Saitama's emissions trading scheme there is one major drawback with the scheme. This downfall is that there is no enforcement in place for failing to comply with the mandatory reduction and reporting of emissions for facilities. Although there have not been reports of issues of non-compliance, there is the possibility for a lack of predictability. If facilities begin to not report their emissions or fail to meet their reduction requirements then the goals of the City will also be impacted. Having in place enforcements can improve the predictability of the scheme and what the outcome will be for the City.

\section{Case Study \#2- Shenzhen, China}

\section{Background}

Shenzhen, a major city located in the Guangdong province of China has a population of just over 10 million people. It is a financial centre for the country thanks to large amounts of foreign investment that took place in the late 1970's. The City holds sub-provincial administrative status meaning it has powers that are only slightly less than Guangdong. The total greenhouse gas emissions for the City which covers both urban and rural areas are $153 \mathrm{MtC0}_{2} \mathrm{e}$ 
(International Carbon Action Partnership, 2017b). The breakdown of the emissions by sector has not been released due to China being protective of their data.

In June 2013 the City implemented a broad strategy emissions trading system that targets several different sectors. This scheme is one of seven pilot studies that is happening in China and was the first one to be implemented of the seven (International Carbon Action Partnership, 2017b). The seven pilot studies are being utilized towards the country's five year plan where the ultimate goal is the creation of a National Emissions Trading Scheme. Shenzhen's emission trading scheme covers the following sectors: industry, power, manufacturing, buildings, port and public transportation. The mandatory inclusion threshold for facilities is based on the type of building it is or the size of the building: enterprises- $3,000 \mathrm{t} / \mathrm{CO} 2$, public buildings- $20,000 \mathrm{~m} 2$, government buildings- $10,000 \mathrm{~m} 2$. This equates to the mandatory participation of 824 facilities and covers $40 \%$ of the city's greenhouse gas emissions.

This emission trading scheme has gone through four year- long periods thus far. Originally the pilots were only supposed to last for three years and be replaced by the national emissions trading scheme in 2016 but that did not happen. The National scheme is now scheduled to be put into effect in the second half of 2017, however the pilots are expected to continue running beyond this (International Carbon Action Partnership, 2017b). The current allowance price of Carbon is approximately 5.46 USD per t/CO2e. It is important to note that unlike most emissions trading schemes that set an absolute cap this scheme uses intensity based targets in the attempt to reduce the carbon of its economy. There is little public information regarding emission targets for each compliance period. However, at the end of Shenzhen's last compliance period which ended in June 2016 they had a 99.8 compliance rate. The intensity 
based target for the City is set at 15\% over 2010 levels. As well, by 2020 the seven pilots have committed to a $45 \%$ reduction in carbon intensity compared to the base year of 2005 .

Throughout the compliance period there is some flexibility in place for facilities. Just like Saitama, banking of credits is allowed but borrowing credits is not (International Carbon Action Partnership, 2017b). The system also allows for offset credits if facilities engage in excess reduction actions specifically for domestic project based carbon offsets. These offset credits can only be used for up to $10 \%$ of the annual compliance period. As well, there are also geographic restrictions in place with them. There is also a provision in place for price management. This provision is in case of market fluctuations, the Shenzhen Development and Reform Commission can sell extra allowances at a fixed cost meaning not impacted by inflation. These allowances cannot be traded and can only be used for compliance.

In order to ensure that facilities are complying with the scheme, there is enforcement in place (International Carbon Action Partnership, 2017b). If information that is provided is false, a fine can be imposed for the difference between reported and actual emissions. The price of the fine is three times the average of the past 6 months. As well, penalties for disrupting the market order can cost up to $\$ 13877.86$ USD. Companies that fail to have enough allowances to match their emissions are fined three times the average market price of the past six months.

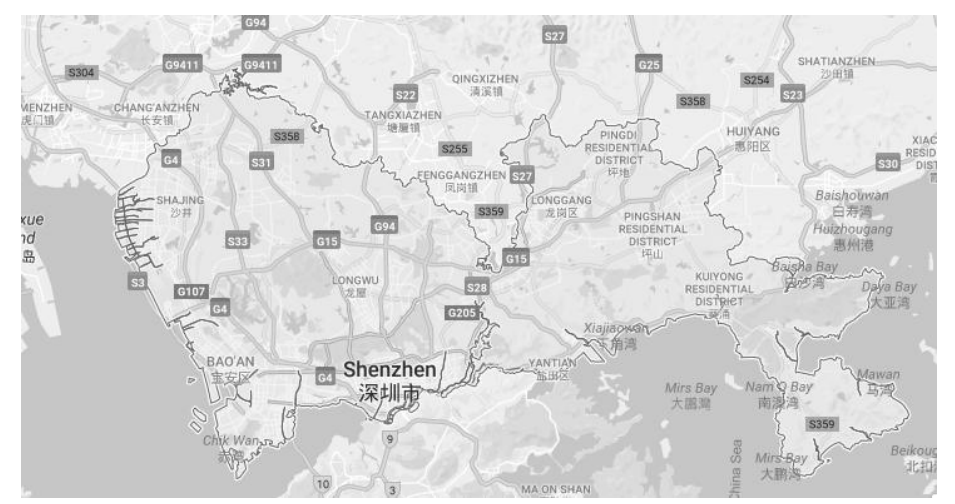

Figure 3. Location of Shenzhen, China (Google Maps, 2017) 


\section{Outcomes- Lessons Learned}

As previously mentioned, following the completion of the compliance period in 2015 , Shenzhen's compliance rate was at $99.8 \%$. Despite this high rate of compliance, information surrounding how far emissions have actually decreased for the City is unknown. The country is very protective of its data and has been known to not report its data to international organizations International Emissions Trading Association (International Emissions Trading Association, 2016). This also means that international companies are not allowed to conduct data verifications within the City. Regardless of this, reports still do suggest that the scheme has been successful to date as subject facilities are completing annual monitoring, reporting and verification of emissions.

One reported reason for the success is the individuals who were involved in the planning of the scheme. The scheme was designed locally by the knowledge of the municipality (International Emissions Trading Association, 2016). There were three groups in particular that worked on the design: relevant provincial and municipal Development and Reform Commission's which is the central planning agency within China, local emissions trading exchanges and leaders at universities and think tanks. Having local governments and individuals in the city create the scheme with assistance from the province meant that the scheme was built with the requirements of the city. Relating the scheme to the city's needs is crucial to its success.

The scheme also reported success because there was the proper funding in place to carry it out (International Emissions Trading Association, 2016). The National Development and Reform Commission as well as the World Bank's Partnership for Market Readiness provided the necessary funds and grants to carry out the scheme. These funds will also be utilized to develop the national system. 
Some issues have arisen with the lack of transparent data and the reliance on a reduction in carbon intensity without an absolute cap (International Emissions Trading Association, 2016). One major issue with the lack of transparency is that this has impacted the behaviour of the market, specifically the demand for carbon allowances. The demand for carbon allowances has been much less than other similar emissions trading schemes. This could also be as a result of not having in place an absolute cap as facilities do not necessarily feel the need to decrease overall emissions. As well, there have been issues with the government giving out too many allowances. This may be due to the fact that with intensity targets, allowances are determined based on results and not forecasts. This is coupled with policy uncertainties of the onset of the national trading scheme and whether banking of allowances will be carried over. Having in place transparent, accessible data and making sure the scheme is taking into account the long term goals of the City is necessary for success.

\section{Case Study \#3- Boulder, Colorado}

\section{Background}

Boulder, Colorado is a mid-sized city located in the United States of America. It is mountainous community situated at the base of the Rocky Mountains. The city is classified as a home rule municipality meaning that is has the capacity to exercise powers and functions that are similar to that of the State Government. It is predominantly a commercial city with a large research sector as a major University is located within the City. The total greenhouse gas emissions for the City is 1.95MtCO2e (City of Boulder, Colorado, 2017) The current breakdown in percentage of the City's emissions by sector is the following: commercial/industrial- $41 \%$, transportation- $31 \%$, residential- $15 \%$, institutional- $12 \%$, waste- $1 \%$ and miscellaneous- $0.3 \%$ (City of Boulder, Colorado, 2017). 
In 2007, the city implemented a specific sector carbon pricing tax that targets electricity and is part of the wider Boulder Climate Action Plan. This Action Plan is an aggressive, city funded plan that contains several programs and services to reduce local greenhouse gas emissions (City of Boulder, Colorado, 2017). Boulder's carbon tax is known as the Climate Action Plan Tax. It was the country's first tax in the levying of carbon emissions and was voted in by $82 \%$ of the City residents (City of Boulder, Colorado). Previously to the implementation of this tax, the City funded energy and greenhouse gas programs through a onetime $\$ 100,000$ grant from the City's general fund as well as a two year increase in the City's trash tax which contributed to an additional $\$ 258,000$ (Brouillard \& Van Pelt, 2007). However, with the short term nature of this income and an increase in public concern, a need for a long-term revenue source was needed which lead to the development of the Climate Action Plan Tax.

The tax is levied on both the residents and the businesses and is based on the amount of electricity consumed (City of Boulder, Colorado). The rate for the tax is divided based on sector: residential- $\$ 0.0049$ per $\mathrm{kWh}$, commercial- $\$ 0.0009$ per $\mathrm{kWh}$ and industrial- $\$ 0.0003$ per $\mathrm{kWh}$. This is the equivalent of the following average annual bill: residential- $\$ 21.00$ USD, commercial $\$ 94.00$ and industrial- $\$ 9,600$. By 2050 the goal is for the City to reduce its emissions by $80 \%$ compared to its baseline in 2005 .

It is approximated that 1.8 million dollars a year is collected from the tax (City of Boulder, Colorado). The current tax expires as of March 31st, 2023. The income collected from the tax is seen as a way to pay for the actions that are discussed throughout the Climate Action Plan. Without these funds the implementation of the plan would be very difficult and many programs would either have to be cut back or removed. The breakdown of where the tax money goes to is the following: commercial programs- $55 \%$, residential programs- $18 \%$, market 
innovation- $16 \%$ and climate commitment-11\%. Some of these programs include energy smart programs for residences and businesses to become more energy efficient including the mandatory participation of rental units in the program, pilot programs to spur market innovation and program tracking, and reporting. An emphasis is also placed on the energy and transportation sector since $97 \%$ of the City's greenhouse gas emissions come from these sectors. All programs and services are also periodically evaluated so that they are operating effectively and meet the needs of the residents.

The tax is collected by a third party company called Xcel Energy which supplies the electric power and natural gas to the City (City of Boulder, Colorado, 2017). Residents and businesses are taxed monthly on their utility bill through a transparent method. Individuals and businesses that utilize renewable energy sources including wind and solar are rewarded and exempt from paying the tax. Once the tax is collected it is then sent to the City Manager. Xcel Energy must also provide the City Manager with monthly reports of the amount of energy utilized, the amount of subsequent tax collected, and the amount of renewable energy being utilized that has been exempted from the tax. Penalties are in place for failing to file or pay in full the tax. The City Manager will estimate the amount of tax that is due and will add on a penalty as well as any generated interest.

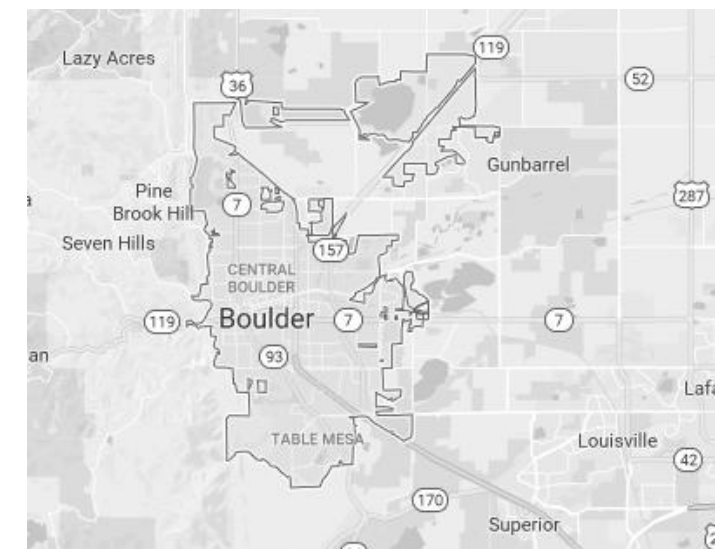

Figure 4. Location of Boulder, Colorado (Google Maps, 2017) 


\section{Outcomes- Lessons Learned}

According to the City government, the City has avoided 147,000 metric tonnes of greenhouse gas emissions thanks to the development of the Climate Action Plan Tax (City of Boulder, Colorado). 147,000 metric tonnes of greenhouse gases is the equivalent of taking 30,000 personal cars off of the road. This number has further been divided by the following energy savings in each sector: energy efficiency- 8,200mt, vehicle travel- 8,400mt, solar$14,3000 \mathrm{mt}$ and hydro-116,100mt. Despite this avoidance in an increase in greenhouse gases, the City's overall level of emissions has stayed relatively constant meaning there has been no significant reductions. The City still sees this as a success as they quote the national economic recession as a major setback in the reductions of emissions. Specifically, the stabilization of emissions in residential energy use and in the waste and vehicle transportation sector has been called great successes for the City.

Some of the successes that have arisen out of the carbon tax can be attributed to the involvement of residents and businesses within it. Homes, businesses, factories and local government buildings account for $68 \%$ the City's greenhouse gas emissions meaning they must play a critical role (City of Boulder, Colorado). On average each resident in the City is responsible for $19 \mathrm{mt}$ of emissions per year and the goal is to reduce this number to $3 \mathrm{mt}$ per person by 2050 . In order to reach this goal, the localized nature of the tax is critical as this means that consumer's actions have a direct impact on the amount of tax that they will be paying. Thus, the decrease in electrical usage or switching to renewable sources of energy directly benefits the consumer through a reduction or omission of the tax. This has contributed to Boulder having one of the highest rates of installed solar capacity per capita in the country and recognition of being a Platinum-level Solar Friendly Community. 
Another reason for the success of the tax is that it creates a dedicated long term funding system which has made the Climate Action Plan that much more successful (Brouillard \& Van Pelt, 2007). This dedicated funding system means that programs and services can be in place to continue to assist with the reduction of emissions. This dedicated funding system is also relatively easy to administer as there is a third party company involved who collects the tax and this tax is only being administered on one utility. Without this dedicated tax on electricity usage, programs that are currently in place will suffer as well as energy advisory services. Like many other cities today, Boulder is continuingly facing a decline in revenue sources and pressures to make budget costs. The only way to put into place the programs laid out in the Climate Action Plan is to have in place this income or else policies would need to re-evaluated.

There are also a few concerns that have arisen with this tax predominantly the tax rate. As previously mentioned there are three different tax rates for the usage of electricity based upon whether it is residential, commercial or industrial. The tax rates are relatively low and could be much higher. As of March 31st, 2023 the tax is up for renewal yet the tax rate will remain the same. With a low tax rate this raises questions of whether or not residents and businesses are continuing to reduce their emissions over a long period of time. Perhaps like in a cap and trade emissions trading scheme where the caps are often reduced over an extended period of time to continuingly lead to a decrease in emissions the same needs to occur with the carbon tax where the tax rate is increased so that Boulder can meet its long term goals.

\section{Case Study \#4-London, England}

\section{Background}

London, England a major city located in south-eastern England has a population of 8.67 million. It is a leading global city specializing in the arts, commerce, education, entertainment, 
fashion, finance, healthcare, media, professional services, research and development, tourism, and transportation. It is also home to Europe's largest economy with five different business districts making it a financial capital. The City is a two tier system meaning that there is a citywide, strategic tier and a local tier. There are 33 smaller municipalities that make up the local tier. The total greenhouse gas emissions for the City are $67 \mathrm{MtCO}_{2} \mathrm{e}$ which makes it world's eighth largest emitter of CO2 (Greater London Authority, 2007). The current breakdown in percentage of the City's emissions by sector is the following: aviation- 34\%, domestic- $25 \%$, commercial \& public sector- $22 \%$, ground based transport- $14 \%$ and industrial- $5 \%$ (Greater London Authority, 2007).

In February 2003, London enacted a carbon emitting behaviour fee, specifically a fee on congestion. London is the largest city to date to have adopted a central area tax scheme. The area of London that is taxed is known as the Congestion Charge Zone and is located in the centre of the City (Transport for London, 2017a). During the first few years of the congestion tax, the zone covered $22 \mathrm{~km} 2$; however this area was increased by $50 \%$ in February 2007. The charge zone is in effect Monday to Friday from 7:00am to 6:00pm. There is no charge for traveling outside those times, on the weekends or on holidays. As well, there is no charge for low emission vehicles. The daily charge is 14.13 USD if paid in advance or on the same time. If users pay the following day the charge is increased to \$17.21USD.

It is estimated that 150 million USD is collected from the fee annually (Transport for London, 2017a). This money goes towards improving transit, increasing the number of buses on the streets, road safety and energy efficiency in transportation. The cost that went into the initial setup of the congestion zone was just over 196 million USD with a \$110 million USD operating 
cost. The additional costs for the expansion of the congestion zone \$172 million USD and an additional $\$ 52$ million dollars in annual operating costs.

In addition to the money collected from the congestion fee, London is in the process of implementing an Ultra Low Emission Zone which will come into effect in September 2020 (Transport for London, 2017b). It will operate 24 hours a day, 7 days a week within the current Congestion Charging Zone. All cars, motorcycles, vans, buses, coaches and heavy good vehicles will need to meet exhaust emission standards or they will have to pay a daily fee. This expansion of the congestion fee is critical because the City is still dealing with elevated, unsafe levels of nitrogen dioxide which contributes to 9,400 deaths in the City each year. Road emissions are contributing to almost $50 \%$ of nitrogen dioxide levels in the atmosphere. This additional program shows the City's dedication to not solely reducing congestion in the city but also air quality and reduction harmful emissions.

The congestion fee is collected with minimal administrative capacity as there are no toll booths in place (Transport for London. (2017a). Instead there are fixed camera at the entrance points on the congestion zone that have the ability to automatically capture the number of the vehicle's licence plate. Enforcements are also in place in the form of penalties for failing to pay in a timely fashion. The penalty charge is $\$ 159.78$ USD with 28 days to pay it. If the fee is paid within the first 14 days then it is reduced by $50 \%$ to $\$ 79.89$ USD. If the penalty is not paid within 28 days then an increase of $50 \%$ will be applied. 


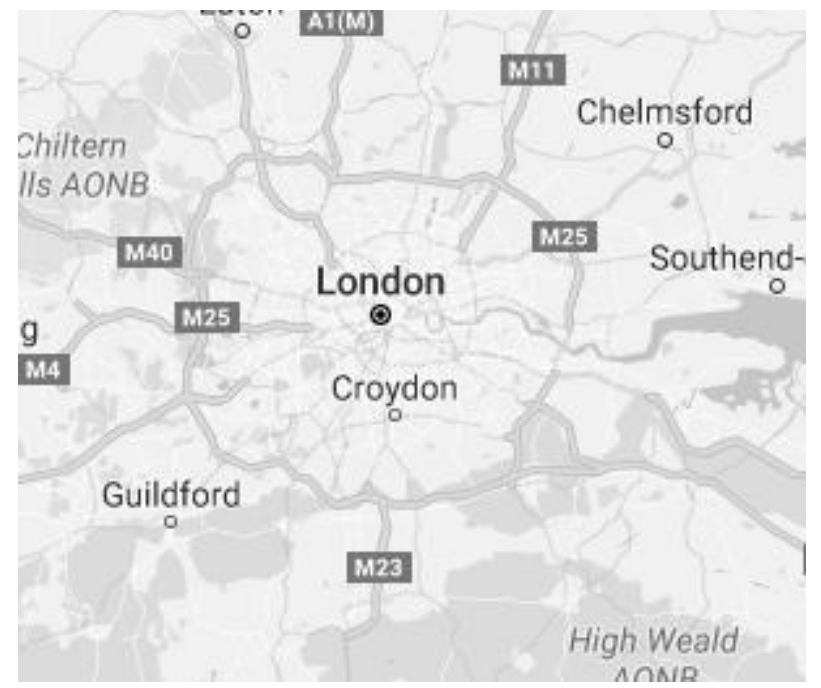

Figure 5. Location of London, England (Google Maps, 2017)

\section{Outcomes- Lessons Learned}

Since the adoption of this carbon fee, London has become the only major city to see a shift away from the personal vehicle to alternative modes of transportation- public transportation, cycling and walking. To date there has been a $20 \%$ reduction in four wheeled traffic within the congestion fee zone which is the same as 75,000 vehicles (C40 Cities, 2011). This is equivalent to 100,000 tonnes of $\mathrm{CO} 2$ emissions annually across the City which means an improvement in air quality. This is due to fewer vehicles on the road and those that are on the road experiencing less congestion. With the decrease in congestion and air pollution there has also been a $66 \%$ increase in cycling levels as an alternative mode of transportation. The expansion of the Ultra Low Emission Zone within the congestion zone will also contribute to the decrease in elevated levels of harmful air pollutants and will leading to the promotion of alternative moods of transportation other than the personal vehicle.

The progress that has been accomplished thus far in the reduction of emissions in the transportation sector can be attributed to several factors. Just like Boulder's carbon fee there is a direct impact on the actions of the individual. Driving a vehicle during the congestion period will have direct impacts on the driver in the form of a fee that must be paid. Thus, there are incentives 
in place for choosing alternative methods of transportation just like there are benefits for reducing electrical usage in the case of Boulder.

As well, with the implementation of the new Ultra Low Emission Zone that is coming into effect in 2020 this will advance the positive impacts of the current fee. Putting a price on the emissions themselves in terms of charging vehicles an additional fee if they do not meet the exhaust emissions standards will continue to lead to a reduction in pollution in the atmosphere.

Although there has been progress made with the ground transportation sector and a decrease in its emissions, this is only one industry contributing to greenhouse gases. Ground transportation only makes up 14\% of the City's greenhouse gas emissions (Greater London Authority, 2007). It acts as a good starting point with the implementation of carbon pricing but there are still other sectors to take into account. Either expanding the carbon fee to other sectors or allowing the funds that are generated to go towards the implementation of other services and programs other than solely the transportation sector can be a part of the solution. 
Table 1. Summary of Characteristics

\begin{tabular}{|c|c|c|c|c|c|c|}
\hline & \multicolumn{6}{|c|}{ Characteristics } \\
\hline & Population & $\begin{array}{c}\text { Overall GHG } \\
\text { Emissions } \\
\text { (Megaton of CO2 } \\
\text { Equivalent) } \\
\end{array}$ & $\begin{array}{c}\text { Type of Trading } \\
\text { Scheme }\end{array}$ & Targeted Sector(s) & $\begin{array}{l}\text { Reduction in } \\
\text { Emissions to } \\
\text { Date }\end{array}$ & $\begin{array}{l}\text { Total Emissions } \\
\text { Reduction Target }\end{array}$ \\
\hline \multicolumn{7}{|l|}{ Cities } \\
\hline $\begin{array}{l}\text { 1. Saitama, } \\
\text { Japan }\end{array}$ & 1.26 million & 38.5 & $\begin{array}{c}\text { Broad Strategy Cap } \\
\& \text { Trade }\end{array}$ & $\begin{array}{c}\text { Commercial, } \\
\text { industrial }\end{array}$ & $24 \%$ reduction & $\begin{array}{l}21 \% \text { reduction by } \\
2020\end{array}$ \\
\hline $\begin{array}{l}\text { 2. Shenzhen, } \\
\text { China }\end{array}$ & 10 million & 153 & $\begin{array}{c}\text { Broad Strategy Cap } \\
\text { \& Trade }\end{array}$ & $\begin{array}{l}\text { Industry, power, } \\
\text { manufacturing, } \\
\text { buildings, port, } \\
\text { public } \\
\text { transportation }\end{array}$ & NA & $\begin{array}{l}45 \% \text { reduction by } \\
2020\end{array}$ \\
\hline $\begin{array}{l}\text { 3. Boulder, } \\
\text { Colorado }\end{array}$ & 103,166 thousand & 1.95 & $\begin{array}{c}\text { Specific Sector } \\
\text { Carbon Tax }\end{array}$ & Electricity & $\begin{array}{l}\text { No Significant } \\
\text { Reductions, } \\
\text { remained } \\
\text { stable }\end{array}$ & $\begin{array}{c}80 \% \text { reduction by } \\
2050\end{array}$ \\
\hline $\begin{array}{l}\text { 4. London, } \\
\text { England }\end{array}$ & 8.67 million & 67 & $\begin{array}{l}\text { Specific Sector } \\
\text { Carbon Fee }\end{array}$ & Transportation & $16 \%$ & $\begin{array}{l}80 \% \text { reduction by } \\
2050\end{array}$ \\
\hline
\end{tabular}




\section{Discussion/ Recommendations}

From the 4 case study cities that have been examined- Saitama, Shenzhen, Boulder and London it is evident that there are strengths and weaknesses with each carbon pricing instruments. These strengths and weaknesses have being turned into a list of criteria that captures what a successful carbon pricing instrument looks like at the local government level. The seven criteria for a successful carbon pricing instrument are as follows: embedded with current policy, prior data and reporting, locally designed, predictable, flexible, enforcement and designated funding. Table 2 provides a short description of what each criterion consists of. Table 3 provides an overview of which criterion each City successfully accomplishes and what they fail to do.

Table 2. List of Criteria for a Successful Carbon Pricing Instrument at the Local Level

\begin{tabular}{|c|c|}
\hline Criteria & Description \\
\hline $\begin{array}{l}\text { Embedded within } \\
\text { Current Policy }\end{array}$ & $\begin{array}{l}\text {-Embedding the carbon pricing instrument within already existing policy } \\
\text { opposed to a standalone policy document }\end{array}$ \\
\hline $\begin{array}{l}\text { Prior Data \& } \\
\text { Reporting }\end{array}$ & $\begin{array}{l}\text {-Collecting data on emissions prior to the implementation of the carbon } \\
\text { pricing instrument }\end{array}$ \\
\hline Locally Designed & $\begin{array}{l}\text {-Ensure that the carbon pricing instrument is designed by locals within } \\
\text { the city including professional and residents living within the city }\end{array}$ \\
\hline Predictable & $\begin{array}{l}\text {-Have in place a clear rules based framework that directly states what the } \\
\text { role of the individual/business is in the carbon pricing instrument so that } \\
\text { there are no surprises }\end{array}$ \\
\hline Flexible & $\begin{array}{l}\text {-Providing different options to offset emissions such as through banking } \\
\text { of carbon credits between compliance periods, or carbon credits provided } \\
\text { for carbon offset projects }\end{array}$ \\
\hline Enforcement & $\begin{array}{l}\text {-Having in place sanctions for non-compliance with the carbon pricing } \\
\text { instrument }\end{array}$ \\
\hline Designated Funding & $\begin{array}{l}\text {-Having in place a direct, continuous funding stream to fund the carbon } \\
\text { pricing instrument }\end{array}$ \\
\hline
\end{tabular}


Table 3. Highlighted Criteria for Successful Carbon Pricing Instruments

\begin{tabular}{|c|c|c|c|c|c|c|c|}
\hline & \multicolumn{7}{|c|}{ Criteria } \\
\hline & $\begin{array}{l}\text { Embedded Within } \\
\text { Current Policy }\end{array}$ & $\begin{array}{l}\text { Prior Data \& } \\
\text { Reporting }\end{array}$ & Locally Designed & Predictable & Flexible & Enforcement & Funding in Place \\
\hline \multicolumn{8}{|l|}{ Cities } \\
\hline $\begin{array}{l}\text { 1. Saitama, } \\
\text { Japan }\end{array}$ & $\checkmark$ & $\checkmark$ & & & $\checkmark$ & & $\checkmark$ \\
\hline $\begin{array}{l}\text { 2. Shenzhen, } \\
\text { China }\end{array}$ & $\checkmark$ & & $\checkmark$ & & $\checkmark$ & $\checkmark$ & $\checkmark$ \\
\hline $\begin{array}{l}\text { 3. Boulder, } \\
\text { Colorado }\end{array}$ & $\checkmark$ & $\checkmark$ & $\checkmark$ & $\checkmark$ & & $\checkmark$ & $\checkmark$ \\
\hline $\begin{array}{l}\text { 4. London, } \\
\text { England }\end{array}$ & & & $\checkmark$ & & & $\checkmark$ & $\checkmark$ \\
\hline
\end{tabular}


As demonstrated in the 4 case studies, a carbon pricing instrument is not likely to capture all 7 criteria. For the City of Toronto, 4 specific recommendations are being proposed that specifically relate to the City. These four recommendations are important in the beginning stages of the implementation of a carbon pricing instrument. They are classified as the following and will be expanded upon below alongside how the 4 case studies informed these recommendations: data and reporting- expansion and updating of the document 'Greenhouse Gas and Air Pollutants in the City of Toronto- toward a Harmonized Strategy for Reducing Emissions', alignment with existing policy specifically Transform TO, long term funding specifically utilizing the funding provided by the Federation of Canadian Municipalities and the Canada Infrastructure Bank and lastly emphasizing local design.

\section{Recommendation \#1- Data and Reporting- Expansion and Updating of 'Greenhouse Gas and Air Pollutants in the City of Toronto- toward a Harmonized Strategy for Reducing Emissions'}

In order for the successful implementation of carbon pricing instruments at the municipal level, having a comprehensive data set in place of current emissions from relevant sectors is recommended prior to the implementation stage. Mandatory reporting of emissions in the years leading up to the implementation of carbon pricing instruments is necessary for successful design of the instrument. Without this emissions data, designing the instrument would be very difficult and may not be successful. Ensuring there is robust experience with monitoring, reporting and verification of emissions data is also critical prior to the implementation stage. Having in place this experience will assist with the administrative capacity of the instrument.

The City of Toronto already has in place an integrated survey of emissions as is represented in the report titled, 'Greenhouse Gas and Air Pollutants in the City of Torontotoward a Harmonized Strategy for Reducing Emissions'. The City already knows that the 
following three sources are the largest contributors to greenhouse gas emissions: natural gas burning (residential and commercial buildings), electricity production and burning of gasoline/ diesel (cars and trucks). Despite this data the City needs to ensure that it is updated and expanded upon and that all of its sectoral data is up to date in order to be able to design and implement successful carbon pricing instruments.

In all 4 case studies, half of them had to some degree mandatory reporting of emissions before the implementation of their carbon pricing instruments. This mandatory reporting of emissions has been one contributing factor in the successfulness of emissions being stabilized or cut in specific sectors. For example, Saitama had in place an Environmental Damage Reduction Program which called for mandatory reporting prior to the implementation on its emissions trading scheme. Having this data in place in vital in order to design the instrument. As well, it is critical for this data to be transparent or issues may arise as was the case with Shenzhen and the behaviour of the market.

One important differentiating factor among the different cities is that although they all had reporting in place for multiple sectors they did not necessarily address all these sectors in their carbon pricing instruments. Cities who either used carbon pricing instruments to address multiple sectors or who used the funds towards addressing broad policies and programs were often more successful with decreasing emissions over a range of sectors. This is opposed to cities like London where only one sector was addressed and the funds collected only went towards that one sector. Only taking into account one sector means others will continue to contribute to greenhouse gases in the atmosphere. 


\section{Recommendation \#2- Alignments with Existing Policy Specifically Transform TO}

The second recommendation that has been informed by the four case studies is the importance of aligning Toronto's carbon pricing instrument with the document called 'Transform TO'. As previously mentioned this document highlights how the City will go about reducing its greenhouse gas emissions and will inform a short term and long term climate strategy. The carbon pricing instrument is more likely to be successful if it is embedded within current policies as opposed to being a standalone policy. Studies have been done that show that carbon pricing instruments function best when they are alongside other policies and instruments and not in isolation (World Bank Group, 2016). When carbon pricing instruments are working alongside complementary policies such as those found in documents like Climate Action Plans, this means that they are directly working to meet the long term policy objectives of the City. In 'Transform TO' targets have already been made including an $80 \%$ reduction in greenhouse gas emissions by 2050. Adding in the action piece, in this case the carbon pricing instrument will allow these goals to be reached.

Three of the four cities that have been looked at have embedded their carbon pricing instruments within already existing policy documents. Of the three, Saitama and Boulder were quite successful. Saitama took its emissions trading scheme and embedded it within its Prefecture Global Warming Strategy Promotion Ordinance. This allows the City to see its long term goals and the actions that will be undertaken in order to reach these goals within one policy document. The City of Boulder, directly related its carbon tax with its climate action plan. It did this by using the funds that were generated from the tax to go towards funding the programs and services that are laid out in Boulder's climate action plan. Thus, having direct alignment between 
carbon pricing instruments and a City's broader climate policy documents are critical for the success of long term goals.

On the other hand, the City of London failed to align its carbon fee with existing policies specifically the document titled, 'Action Today to Protect Tomorrow, the Mayor's Climate Change Action Plan' which lays out the current status of emissions in the City and corresponding actions to address these emissions. The carbon fee only addresses the ground based transportation sector but the action plan lays out four other sectors that are contributing to emissions. Yet, these other sectors are not accounted for in the existing carbon fee thus, representing a disconnection between the two.

\section{Recommendation \#3- Long Term Funding Utilizing Funding Provided by the Federation of Canadian Municipalities and the Canada Infrastructure Bank}

The third recommendation for the successful implementation of a carbon pricing instrument for the City of Toronto is the necessity of having long term funding in place specifically utilizing the funding provided by the Federation of Canadian Municipalities and the Canada Infrastructure Bank. As previously mentioned, the Federation of Canadian Municipalities has in place two programs called the Municipalities for Climate Innovation Program and the Green Municipal Fund. These programs provide funding and grants to support municipalities who are looking to reduce their greenhouse gas emissions.

The Canada Infrastructure Bank which is in the process of being set up is another funding source that Municipalities will be able to tap into. It will provide low cost financing for new infrastructure projects for provincial and municipal levels of government. The Bank will allow governments to borrow funds at the Federal government rate making it easier and more affordable for communities to build projects that they need. As well, there will be dedicated 
funding that is allotted to green infrastructure projects ranging from climate resiliency infrastructure to clean energy.

Tapping into these funding sources will allow the City to have a designated funding source for the beginning stages of the implementation of a carbon pricing instrument. These funds would allow Toronto to both update its current emissions inventory which is discussed in recommendation number one and put into place the necessary actions to reach its $80 \%$ emissions reduction by 2050 .

In the four case studies examined, it is apparent that they all had in place long term funding for the implementation of their carbon pricing instruments. Having in place proper funding ensures that the instrument is carried out properly and that the necessary resources and expertise are in place. Not only having designated funding during the implementation stages but also throughout is also important. Boulder, Colorado has been very successful as this as the carbon action tax generates the dedicated funding system for the implementation of programs and services to assist the City with the reduction of emissions. Thus, creating long term designated funding. London has also been successful with creating a long term funding source through its fee on congestion, however the funds that are being collected from this fee will need to be expanded to ensure that all sectors contributing to greenhouse gas emissions are being addressed.

\section{Recommendation \#4- Locally Designed}

The final recommendation that has been informed by the four case studies is taking into account the design of the carbon pricing instrument stressing the importance of local design. It is important that the design of the instrument is done by those working within Toronto City Hall as well as experts from the local Universities. Consulting residents within Toronto is also crucial. 
Public engagement will be critical, not only to inform residents what their role will be but also to listen to suggestions and to implement this feedback. This will ensure that the design of the instrument is done with the requirements of the City in mind.

Not only is it important to take into account who is designing the instrument but when the instrument has a direct impact on businesses and residents that are residing within the City they are more likely to adjust their actions as they were involved with the design process. Thus, designing with local in mind in vital to the instruments success.

Of the four cities that have been examined, Shenzhen and Boulder were the most successful in designing their instruments with local in mind. Shenzhen designed its instrument with 3 key players: relevant provincial and municipal Development and Reform Commission's which is the central planning agency within China, local emissions trading exchanges and leaders at universities and think tanks. This shows the City's dedication to creating an instrument that actually meets the needs of its residents. On the other hand, Boulder's instrument was successful because the local government consulted with its residents to ask them how much they would be willing to be pay as they had previously mentioned that the trash tax that was in place for two years was too excessive. Reducing the tax rates of their climate tax below the levels of the previous trash tax met the needs of the residents and also contributed to meeting the long term climate change goals of the City. 


\section{Limitations}

This study realizes that there are some limitations in place for municipal governments to be able to implement carbon pricing instruments. The structure of government is one major limitation. Not all municipal governments have the power to put into place new funding mechanisms without the approval of higher levels of government. The City of Toronto would likely have to consult with the province and get the provinces approval before being able to implement a carbon pricing mechanisms which would generate funds for City services. Although the City does have additional administrative powers through the City of Toronto Act these powers may not be enough.

Another limitation that the study recognizes is that municipal governments do not work in an isolated environment. The City of Toronto is a creature of the province just like many other local governments (Gore, et al., 2012). National policies often dictate what a municipal government can do. Thus, it is that much more important for Toronto to work with higher levels of government as this will lead to formation of national policies to address climate change and will broaden the range of environmental options for municipal governments. As well, national support will lead to necessary resources, tools and technical information to implement carbon pricing instruments. Governments must think globally but act locally. Having in place a strong framework that takes into account the role of all levels of government is crucial.

The third limitation that this study recognizes is that the size of the municipality may impact upon the ability for it to implement carbon pricing instruments (Robinson \& Gore, 2005). It has been shown that larger municipalities are more likely to involve themselves in climate change work. Having in place the expertise, funding, and the time to implement these actions are all necessary factors and possible barriers for municipalities. 
The final limitation of the study is that it recognizes that it does not present an exhaustive list of recommendations for municipal governments to implement carbon pricing instruments. It provides a starting place for local governments to work with other levels of government to successfully implement carbon pricing instruments to reduce greenhouse gases in the atmosphere. 


\section{Conclusion}

Cities play a crucial role in the fight against climate change. They are home to top researchers, municipal leaders and post secondary institutions that are working together to come up with innovative solutions to fight climate change. Through collaborative knowledge, cities have the capacity to improve the quality of life for its residents. Carbon pricing mechanisms offer a unique approach for cities to accomplish this. Emissions trading schemes, carbon taxes and carbon fees have been proven to reduce emissions within cities. Not only our greenhouse gas emissions being reduced but through the implementation of carbon pricing instruments revenue is generated at the Municipal level. This generated revenue has the capacity to go towards green infrastructure projects that the community may otherwise not be able to afford.

It is important to take into account that no two cities are the same when addressing which climate pricing instrument is the most effective for any given city. Yet, through cooperation across stakeholders including different levels of government and different sectors there is an opportunity for strong collaboration and ultimately success in the fight against climate change.

Saitama, Shenzhen, Boulder and London are four distinct Cities that have shined light on the successfulness of different carbon pricing instruments. Although each instrument is different in terms of its design and implementation techniques they all have the same goal in mindreducing greenhouse gas emissions and making cities more livable. The four cities have provided invaluable information that has been used to inform the beginning stages of a comprehensive list of recommendations for other municipal governments to refer to. These recommendations are meant to be built upon as city leaders continue to expand upon carbon pricing instruments and work towards creating sustainable places for it residents and businesses. 


\section{Reference List}

Brouillard., C \& Van Pelt., S. (2007, February). A community takes charge: Boulder's carbon tax. Retrieved from https://www-static.bouldercolorado.gov/docs/community-takescharge-boulders-carbon-tax1201305081136.pdf?_ga=1.191322986. 1794976096.1484944107

C40 Cities. (2011, November 3). London's congestion charge cuts CO2 emissions by 16\%. Retrieved from http://www.c40.org/case_studies/londons-congestion-charge-cuts-co2emissions-by-16

City of Boulder, Colorado. Boulder climate action plan factsheet. Retrieved from https://wwwstatic.bouldercolorado.gov/docs/CAP_document_FINAL-1201603211302.pdf?_ga=1.151814137.1794976096.1484944107

City of Boulder, Colorado. (2017, January). Boulder's climate commitment rising to the climate challenge, powering a vibrant future. Retrieved from https://wwwstatic.bouldercolorado.gov/docs/January_Climate_Commitment_Draft_1.17_low_res-1201701241028.pdf?_ga=1.182812518.1794976096.1484944107

City of Toronto (2007a, June). Change is in the air climate change, clean air and sustainable energy action plan: moving from framework to action phase 1 . Retrieved from https://www1.toronto.ca/City\%200f\%20Toronto/Environment\%20and\%20Energy/Progr ams\%20for\%20Residents/Files/pdf/C/clean_air_action_plan.pdf

City of Toronto. (2007b, June). Greenhouse gases and air pollutants in the city of Toronto towards a harmonized strategy for reducing emissions. Retrieved from https://www1.toronto.ca/city_of_toronto/environment_and_energy/key_priorities/files/pd f/ghg-aq-inventory-june2007.pdf

City of Toronto. (2011, December). Toronto's future weather and climate driver study volume 1overview. Retrieved from http://www1.toronto.ca/city_of_toronto/environment _and_energy/key_priorities/files/pdf/tfwcds-full-report.pdf

City of Toronto. (2015, December 17). Toronto's 2013 greenhouse gas inventory staff report. Retrieved from http://www.toronto.ca/legdocs/mmis/2016/pe/bgrd/backgroundfile87697.pdf

City of Toronto. (2016, November). Transform TO: climate action for a healthy, equitable and prosperous Toronto. Retrieved from http://www1.toronto.ca/City\%20Of\%20Toronto/ Environment\%20and\%20Energy/Climate\%20and\%20Energy\%20Goals/Transform\%20T O/PDFs/Final_TransformTO_Report1_Feb23.pdf

David Suzuki Foundation. (2014). Carbon tax or cap-and trade? Retrieved from http://www.davidsuzuki.org/issues/climate-change/science/climate-solutions/carbon-taxor-cap-and-trade/ 
Environmental Commissioner of Ontario. (2015, July). Feeling the heat: greenhouse gas progress report. Retrieved from http://docs.assets.eco.on.ca/reports/climatechange/2015/2015-GHG.pdf

Federation of Canadian Municipalities. (2017). Retrieved from http://www.fcm.ca/home.htm

Gore, Christopher, Pamela Robinson, \& Richard Stren. (2012). Governance and climate change: assessing and learning from Canadian Cities: In cities and climate change: responding to an urgent agenda (Vol. 2 of 2), edited by Daniel Hoornweg, Mila Freire, Marcus J. Lee, Perinaz Bhada-Tata and Belinda Yuen. World Bank: Washington DC, pp. 498-523.

Government of Canada. (2016). Pan-Canadian framework on clean growth and climate change. Retrieved from https://www.canada.ca/content/dam/themes/environment/documents/ weather1/20161209-1-en.pdf

Government of Ontario. (2017). Ontario population projections update, 2015-2041. Retrieved from http://www.fin.gov.on.ca/en/economy/demographics/projections/

Greater London Authority. (2007). Action today to protect tomorrow, the Mayor's climate change action plan executive summary. Retrieved from http://www.energyforlondon.org/wp-content/uploads/2016/07/CCAP-2007.pdf

Innovation Network for Communities. (2015, July). Cities and carbon emissions pricing, a report to the Summit Foundation. Retrieved from http://www.in4c.net/files/Cities-andCarbon-Emissions-Pricing-Final-Report-7.2.15.pdf

Intergovernmental Panel on Climate Change. (2014). Climate change 2014 synthesis report. Retrieved from https://www.ipcc.ch/pdf/assessmentreport/ar5/syr/SYR_ AR5_FINAL_full_wcover.pdf

International Carbon Action Partnership. (2017a, February 10). Japan Saitama target setting emissions trading system. Retrieved from https://icapcarbonaction.com/en/ets-map

International Carbon Action Partnership. (2017b, February 10). China- Shenzhen pilot system. Retrieved from https://icapcarbonaction.com/en/ets-map

International Carbon Action Partnership (2017c, February 10). Emissions trading scheme map. Retrieved from https://icapcarbonaction.com/en/ets-map

International Emissions Trading Association. (2013, September). A users guide to emissions trading in China. Retrieved from http://www.ieta.org/Resources/Resources/Reports/ieta _emissionstrading_china_usersguide_sept2013_draft_a4_sf.pdf

International Emissions Trading Association. (2016, March). China's national emissions trading system. Retrieved from http://www.ieta.org/resources/China/Chinas_National_ 
ETS_Implications_for_Carbon_Markets_and_Trade_ICTSD_March2016_Jeff_Swartz.pf

Liberal Party of Canada. (2017). An historic investment plan to strengthen the middle class, create jobs, and grow our economy. Retrieved from https://www.liberal.ca/wpcontent/uploads/2015/08/An-historic-investment-plan.pdf

Linkhart, D. (2016). What are Cities Doing to Address Climate Change? National Civic Review, 105: 24-29. doi:10.1002/ncr.21279

Ministry of Environment and Climate Change. (2017, February 28). Cap and trade. Retrieved from https://www.ontario.ca/page/cap-and-trade

OECD. (2014, September). Cities and climate change policy perspectives. Retrieved from https://www.oecd.org/env/cc/Cities-and-climate-change-2014-Policy-Perspectives-Finalweb.pdf

Robinson, P. J., \& Gore, C. D. (2005). Barriers to Canadian municipal response to climate change. Canadian Journal of Urban Research, 14(1), 102.

Salon, D., Sperling, D., Meier, A., Murphy, S., Gorham, R., \& Barrett, J. (2010). City carbon budgets: A proposal to align incentives for climate-friendly communities. Energy Policy, 38(4), 2032-2041.

Transport for London. (2017a). Congestion charge. Retrieved from https://tfl.gov.uk/corporate/publications-and-reports/congestion-charge

Transport for London. (2017b). Ultra Low Emission Zone. Retrieved from https://tfl.gov.uk/modes/driving/ultra-low-emission-zone?cid=ultra-low-emissionzone\#ton-this-page-5

World Bank Group. (2013, June). Tokyo's emissions trading system. Retrieved from http://documents.worldbank.org/curated/en/607981468253741772/pdf/810580BRI0Toky 00Box379819B00PUBLIC0.pdf

World Bank Group. (2016, October). State and trends of carbon pricing. Retrieved from https://openknowledge.worldbank.org/bitstream/handle/10986/25160/9781464810015.pd $\mathrm{f}$ ?sequence $=7 \&$ is Allowed $=\mathrm{y}$

World Bank Group. (2017). Pricing Carbon. Retrieved from http://www.worldbank.org /en/programs/pricing-carbon 